\title{
Influence of Copper Addition and Temperature on the Kinetics of Austempering in Ductile Iron
}

\author{
YOGEV AMRAN, ALEXANDER KATSMAN, PETER SCHAAF, \\ and MENACHEM BAMBERGER
}

\begin{abstract}
Austempered ductile iron (ADI) is a material that exhibits excellent mechanical properties because of its special microstructure, combining ferrite and austenite supersaturated with carbon. Two ADI alloys, Fe-3.5 pet C-2.5 pet Si and Fe-3.6 pet C-2.7 pet Si-0.7 pet Cu, austempered for various times at $623 \mathrm{~K}\left(350{ }^{\circ} \mathrm{C}\right)$ and $673 \mathrm{~K}\left(400{ }^{\circ} \mathrm{C}\right)$ followed by water quenching, were investigated. The first ferrite needles nucleate mainly at the graphite/austenite interface. The austenite and ferrite weight fractions increase with the austempering time until stabilization is reached. The increase in the lattice parameter of the austenite during austempering corresponds to an increase of carbon content in the austenite. The increase in the ferrite weight fraction is associated with a decrease in microhardness. As the austempering temperature increases, the ferrite weight fraction decreases, the high carbon austenite weight fraction increases, but the carbon content in the latter decreases. Copper addition increases the high carbon austenite weight fraction. The results are discussed based on the phases composing the Fe-2Si-C system.
\end{abstract}

DOI: $10.1007 / \mathrm{s} 11663-010-9388-\mathrm{y}$

(C) The Minerals, Metals \& Materials Society and ASM International 2010

\section{INTRODUCTION}

AUSTEMPERED ductile iron (ADI) is a highly attractive material for technical applications. ${ }^{[1-4]}$ The ADI, which is a nodular cast iron that undergoes a specially designed heat treatment, offers a good alternative to steels and aluminum alloys when high strength, good ductility, and low wear are required.

The properties of ADI depend on the weight fractions and the morphology of ferrite and austenite in the microstructure formed during austempering. The final microstructure strongly depends on the initial composition and phase transformation kinetics during austempering. The typical chemical composition of the ductile iron is Fe-3.5 pet C-2.5 pet Si- 0.4 pet $\mathrm{Mn}-0.05$ pet $\mathrm{Mg}$, but $\mathrm{Cu}$ might also be used to control the pearlitic transformation during the heat treatment. The heat treatment consists of the following two stages: (1) austenization at high temperature ranging between $1123 \mathrm{~K}\left(850{ }^{\circ} \mathrm{C}\right)$ to $1223 \mathrm{~K}\left(950{ }^{\circ} \mathrm{C}\right)$ for the period

YOGEV AMRAN, formerly Graduate Student, Department of Materials Engineering, Technion-Israel Institute of Technology, Haifa 32000, Israel, is now Engineer, Israel Institute of Metals, Technion R\&D Foundation, Haifa 32000, Israel. Contact e-mail: yogev1@ technion.ac.il ALEXANDER KATSMAN, Senior Researcher, and MENACHEM BAMBERGER, Professor, are with the Department of Materials Engineering, Technion-Israel Institute of Technology, Haifa 32000, Israel. PETER SCHAAF, Professor, is with the Department of Materials for Electronics, Institute of Materials Engineering and Institute of Micro- and Nanotechnologies, Ilmenau University of Technology, 98684 Ilmenau, Germany, and with the University of Göttingen, II. Institute of Physics, 37077 Göttingen, Germany.

Dedicated to the memory of Professor B.Z. Weiss, Technion, Israel, and Professor U. Draugelates, TU Clausthal, Germany.

Manuscript submitted November 18, 2009.

Article published online June 8, 2010. required to ensure that the matrix is fully austenitic, followed by rapid cooling to the austempering temperature; and (2) austempering - holding at a temperature $\mathrm{T}_{\mathrm{A}}$ below the bainite start temperature, in the range of $523 \div 723 \mathrm{~K}\left(250 \div 450{ }^{\circ} \mathrm{C}\right)$, for a long time until the required microstructure in achieved. Finally, the samples are cooled by water quenching.

At the austempering temperature, the following two reactions may take place in a sequential order ${ }^{[1]}$.

(a) Ausferrite transformation, in which the homogenous austenitic matrix transforms to ausferrite - a mixture of ferrite ( $\alpha$, bcc structure) and high carbon austenite (hc- $\gamma$, fcc structure).

(b) After a long enough dwell time, the hc- $\gamma$ decomposes to ferrite and iron carbides, the microstructure known as bainite. The carbides reduce the mechanical properties ${ }^{[1-3]}$ of ADI, and therefore, the second reaction should be eliminated.

The final ADI microstructure is composed of spheroidal graphite embedded in the ausferrite matrix. Small amounts of martensite and/or carbides may also be present in the microstructure.

The weight fractions of ferrite and high-carbon $\gamma$ in the ausferrite depend on the austempering temperature and on the carbon content in the austenite at the austenization temperature. The latter can be influenced by austenite stabilizers, such as copper. The austempering temperature also influences the driving force for austenite/ferrite transformation, and by this way it may lead to different sizes of ferrite needles and different kinetics of the ausferrite transformation.

The changes in the amounts of phases occurred during the austempering were reported in a previous article. ${ }^{[5]}$ This study focuses on the ausferrite transition 
kinetics and the influence of austempering temperature and $\mathrm{Cu}$ addition on the ausferrite content.

\section{EXPERIMENTAL PROCEDURES}

The compositions of two ADI alloys studied in the current work are given in Table I. $20 \mathrm{~mm}$ thick plates were cast in bentonite sand molds by ACO Guss GmbH (Kaiserslautern, Germany). As-cast samples of both alloys, machined in the form of $6 \mathrm{~mm}$ bars in diameter, were subjected to austenization in air at $1173 \mathrm{~K}\left(900{ }^{\circ} \mathrm{C}\right)$ for 90 minutes. The austenitized samples were transferred rapidly to a salt bath at $673 \mathrm{~K}\left(400{ }^{\circ} \mathrm{C}\right)$ for austempering for various time durations from 3 minutes up to 110 minutes, followed by water quenching. Additional samples of alloy II were austempered at $623 \mathrm{~K}\left(350^{\circ} \mathrm{C}\right)$ for various time durations up to 180 minutes, followed by water quenching.

In all cases, one sample was water quenched after austenization (austempering time $=0$ ).

The samples were analyzed by optical microscopy, X-ray diffraction (XRD), scanning electron microscopy (SEM), transmission electron microscopy (TEM), and microhardness measurements.

The samples of alloy II austempered at $673 \mathrm{~K}$ $\left(400{ }^{\circ} \mathrm{C}\right)$ were examined by color metallography at Technische Universität München, Germany. The specimens for color microscopy were ground to a $0.05-\mu \mathrm{m}$ grade and then etched with Beracha-Martensite etchant. ${ }^{[5]}$ The microstructures are presented in black and white. The specimens for XRD were ground and polished up to a $1-\mu \mathrm{m}$ grade. The XRD measurements were performed in a conventional automatic powder X-ray diffractometer (Philips PW-1830 generator, Almelo, The Netherlands) with a $\mathrm{Cu}-\mathrm{K} \alpha$ tube operated at $40 \mathrm{~mA}$ and $40 \mathrm{kV}$. 2 $2 \theta$-scans were obtained in the range of $38 \mathrm{deg}$ to $125 \mathrm{deg}$, with a step size of $0.04 \mathrm{deg}$ and exposure time of 6 seconds per step. The specimens for SEM were ground and polished up to a $1 \mu \mathrm{m}$ grade and then etched in 2 pct nital for several seconds. A FEI E-SEM Quanta 200 (Hillsboro, OR) was used to take pictures in secondary electron (SE) mode. The specimens for TEM were cut to discs $3 \mathrm{~mm}$ in diameter and ground to a thickness of $\sim 90 \mu \mathrm{m}$. A spherical dimple was created by a Gatan 656 dimple grinder and polished using $1-\mu \mathrm{m}$ diamond compound and lubricant until the thickness was reduced to $\sim 15 \mu \mathrm{m}$. A Gatan 691 Precision Ion Polishing System (Pleasanton, CA) with Ar ions was used to create a hole. A $200 \mathrm{keV} \mathrm{FEI} \mathrm{Tecnai}$ $\mathrm{G}^{2}$ T20 TEM (Hillsboro, OR) with a $\mathrm{LaB}_{6}$ electron source was used to identify the various phases. The bright field (BF) images were recorded using a Gatan 694 slow scan charge-coupled device camera. The samples for microhardness measurements were prepared similarly to samples for XRD analysis. The Vickers microhardness measurements were carried out using a DMH-2 microhardness tester (Matsuzawa Seiks Co. Ltd, Tokyo, Japan). The load level was set at 300 grams and the load time was 15 seconds.

\section{RESULTS}

The typical microstructures of alloy II austempered at $673 \mathrm{~K}\left(400{ }^{\circ} \mathrm{C}\right)$ for different durations are presented in Figure 1. The microstructures of alloy I austempered at $673 \mathrm{~K}\left(400{ }^{\circ} \mathrm{C}\right)$ and of alloy II austempered at $623 \mathrm{~K}$ $\left(350{ }^{\circ} \mathrm{C}\right)$ were similar. The spheres are graphite and the black phase is martensite formed during water quenching. The bright area near the graphite is composed of ferrite needles surrounded by austenite. From Figure 1, it can be observed that the amounts of the ferrite needles and austenite increase, whereas that of martensite decreases with austempering time.

As can be shown from Figure 1(a), the first ferrite needles form in the vicinity of the graphite nodules. The average graphite diameter $2 \mathrm{R}$ and the average distance between graphite nodules 1 , are listed in Table II.

A typical full-range XRD pattern taken from alloy II austempered for 9 minutes at $673 \mathrm{~K}\left(400{ }^{\circ} \mathrm{C}\right)$ is presented in Figure 2. A Rietveld analysis was used to calculate the weight fractions of the phases presented and their lattice parameters. The change with austempering time of the weight fractions of the various phases in alloy II austempered at $673 \mathrm{~K}\left(400{ }^{\circ} \mathrm{C}\right)$ is presented in Figure 3. The weight fractions were calculated ignoring the graphite phase, because the graphite amount does not change during austempering (the area fractions of graphite were measured by image analysis and were found to be 9.17 pct \pm 1.17 pct and 7.39 pct \pm 0.45 pct for alloy I and II, correspondingly). After austenization for 90 minutes at $1173 \mathrm{~K}\left(900^{\circ} \mathrm{C}\right)$, the samples consisted of austenite and graphite, and the austenite transformed completely to martensite during water quenching (austempering time $=0$ ). During the first 20 minutes of austempering, followed by water quenching, the martensite weight fraction decreased gradually, whereas the weight fractions of austenite and ferrite increased. After austempering for $\sim 25$ minutes, the weight fractions of ferrite and austenite stabilized and reached the values of $65 \mathrm{wt}$ pct and $35 \mathrm{wt}$ pct, respectively. Alloys I and II, austempered at $673 \mathrm{~K}\left(400^{\circ} \mathrm{C}\right)$ and $623 \mathrm{~K}\left(350{ }^{\circ} \mathrm{C}\right)$, respectively, showed similar behavior. The corresponding maximum weight fractions and stabilization times are listed in Table III.

The lattice parameters of austenite determined by XRD are presented in Figure 4. The austenite lattice

Table I. Chemical Composition (Wt Pet) of the Used ADI Samples (Measured by Optical Emission Spectrometer)

\begin{tabular}{lcccccccccccccccc}
\hline & $\mathrm{Fe}$ & $\mathrm{C}$ & $\mathrm{Si}$ & $\mathrm{Cu}$ & $\mathrm{Mn}$ & $\mathrm{Mg}$ & $\mathrm{P}$ & $\mathrm{S}$ & $\mathrm{Cr}$ & $\mathrm{Mo}$ & $\mathrm{Ni}$ & $\mathrm{Ti}$ & $\mathrm{Pb}$ & $\mathrm{Sn}$ & $\mathrm{Zn}$ \\
\hline Alloy I & Bal. & 3.510 & 2.490 & 0.019 & 0.230 & 0.054 & 0.029 & 0.003 & 0.030 & $<0.001$ & 0.041 & 0.002 & $<0.001$ & 0.004 & $<0.001$ \\
Alloy II & Bal. & 3.650 & 2.730 & 0.723 & 0.420 & 0.057 & 0.040 & 0.006 & 0.030 & $<0.001$ & 0.021 & 0.003 & 0.002 & 0.004 & $<0.001$ \\
\hline
\end{tabular}



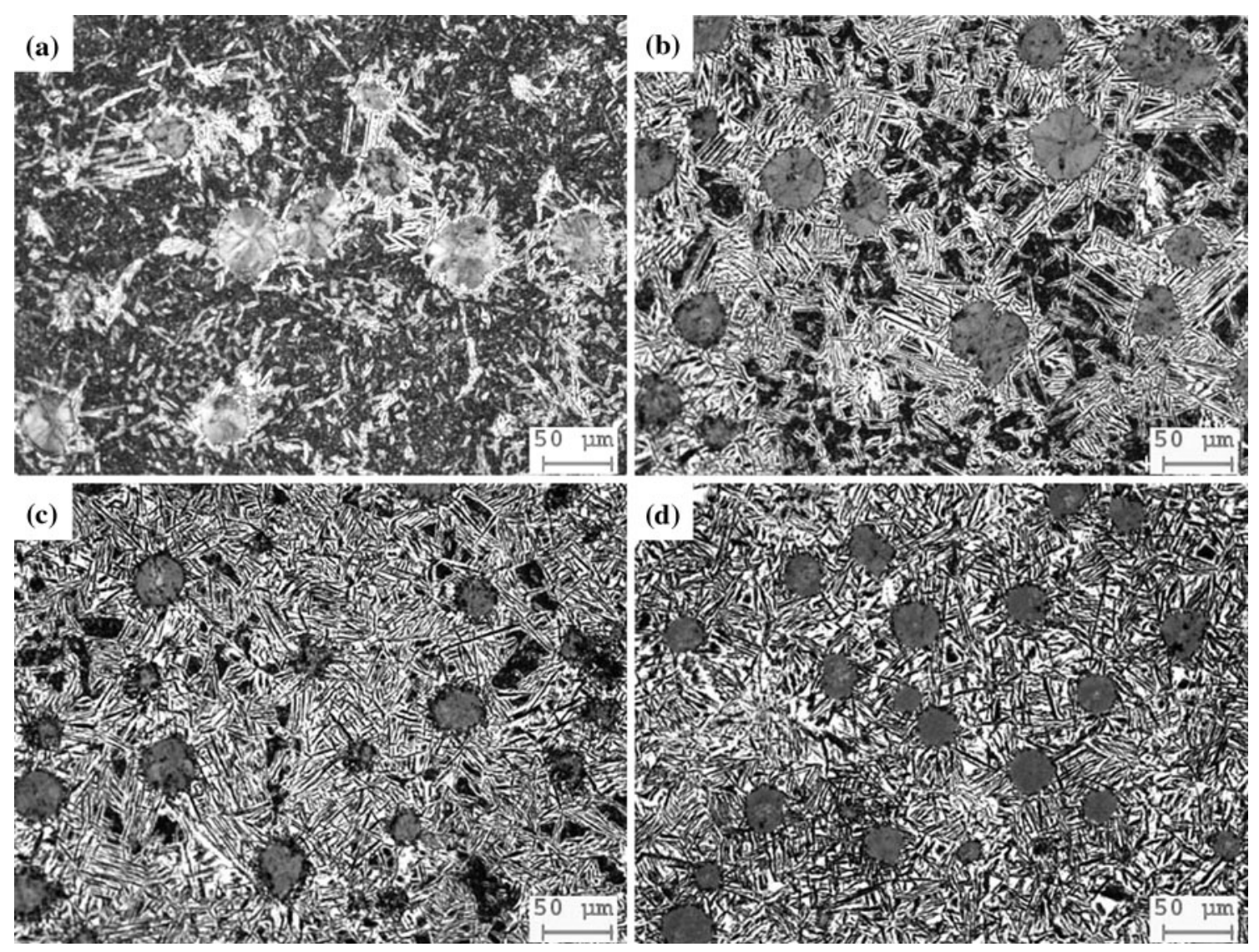

Fig. 1-Typical microstructures of alloy II austempered at $673 \mathrm{~K}\left(400^{\circ} \mathrm{C}\right)$ for different times. (a) $3 \mathrm{~min},(b) 9 \mathrm{~min},(c) 16 \mathrm{~min}$, and $(d) 50 \mathrm{~min}$.

Table II. Characteristic Dimensions of Graphite and Ferrite* for the Various Alloys and Various Austempering Conditions

\begin{tabular}{|c|c|c|c|c|}
\hline & \multicolumn{2}{|c|}{ Graphite nodules } & \multicolumn{2}{|c|}{ Ferrite needles } \\
\hline & $2 \mathrm{R}(\mu \mathrm{m})$ & $1(\mu \mathrm{m})$ & $\mathrm{a}(\mu \mathrm{m})$ & $\mathrm{b}(\mu \mathrm{m})$ \\
\hline $673 \mathrm{~K}\left(400^{\circ} \mathrm{C}\right)$, alloy $\mathrm{I}, 3 \mathrm{~min}$ & $23.6 \pm 8.4$ & $71.9 \pm 22.8$ & $0.31 \pm 0.04$ & $1.60 \pm 0.40$ \\
\hline $673 \mathrm{~K}\left(400^{\circ} \mathrm{C}\right)$, alloy II, $3 \mathrm{~min}$ & $33.3 \pm 6.3$ & $96.2 \pm 35.1$ & $0.19 \pm 0.01$ & $1.13 \pm 0.02$ \\
\hline $623 \mathrm{~K}\left(350^{\circ} \mathrm{C}\right)$, alloy II, $5 \mathrm{~min}$ & $21.9 \pm 13.4$ & $76.4 \pm 38.7$ & $0.19 \pm 0.02$ & $0.85 \pm 0.5$ \\
\hline
\end{tabular}

parameter increases with austempering time and reaches a constant value. Using the relation ${ }^{[6]}$

$$
\mathrm{a}_{\gamma}=3.548+0.044 \mathrm{c}_{\gamma}
$$

where $\mathrm{a}_{\gamma}$ is the austenite lattice parameter (in $\AA$ ) and $\mathrm{c}_{\gamma}$ is the carbon content in the austenite (in wt pct), the carbon content in the austenite can be calculated. As can be observed from Figure 5, the carbon content in the austenite increases with austempering time and reaches the saturated value. The ferrite lattice parameter, determined by XRD, does not change during austempering, simply because of the very low dissolution of carbon in the ferrite.

A typical SE image of alloy II austempered at $673 \mathrm{~K}$ $\left(400{ }^{\circ} \mathrm{C}\right.$ ) for 3 minutes is presented in Figure 6. Most of the ferrite units (see arrows in Figure 6) have a needle-like shape. The small and large average dimensions of the ferrite needles from both alloys austempered at $673 \mathrm{~K}\left(400{ }^{\circ} \mathrm{C}\right)$ for 3 minutes and at $623 \mathrm{~K}\left(350{ }^{\circ} \mathrm{C}\right)$ for 5 minutes, $a$ and $b$, are listed in Table II.

To identify the various phases, samples of alloy II austempered at $673 \mathrm{~K}\left(400{ }^{\circ} \mathrm{C}\right)$ were investigated by TEM using selected area diffraction (SAD). A typical $\mathrm{BF}$ image and related electron diffractions of the phases present in a sample austempered at $673 \mathrm{~K}\left(400{ }^{\circ} \mathrm{C}\right)$ for 6 minutes are presented in Figure 7. As can be observed, the hc- $\gamma$ is located around the ferrite needle.

The variation of the Vickers microhardness of samples austempered from both alloys at $623 \mathrm{~K}\left(350{ }^{\circ} \mathrm{C}\right)$ and $673 \mathrm{~K}\left(400^{\circ} \mathrm{C}\right)$ as a function of time is presented in Figure 8. The microhardness decreases during the first 20-30 minutes of austempering and then reaches 


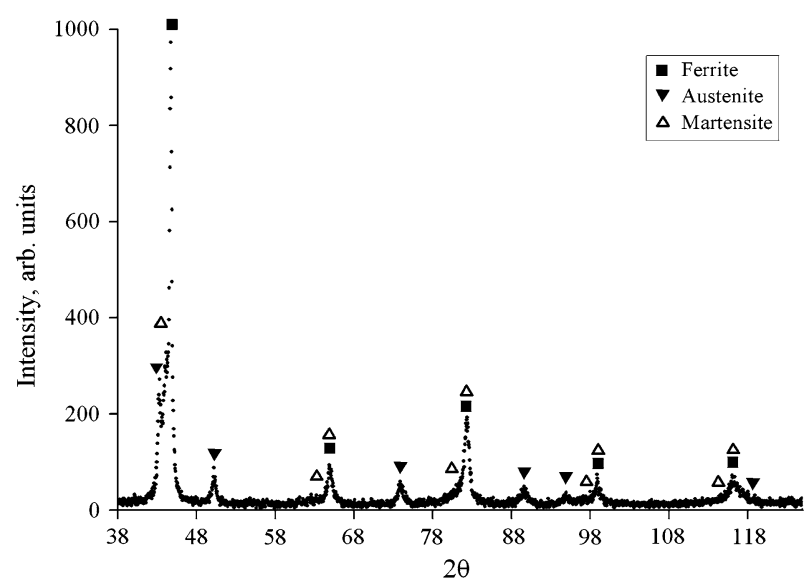

Fig. 2-X-ray diffraction pattern of an alloy II austempered for $9 \mathrm{~min}$ at $673 \mathrm{~K}\left(400{ }^{\circ} \mathrm{C}\right)$. The reflections of ferrite, austenite, and martensite are marked.

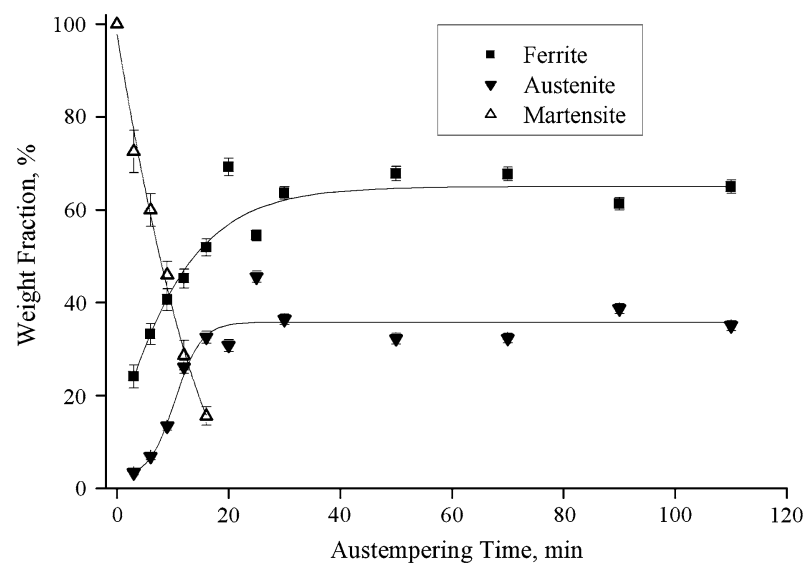

Fig. 3-The weight fractions of ferrite, austenite, and martensite of alloy II austempered at $673 \mathrm{~K}\left(400{ }^{\circ} \mathrm{C}\right)$ vs the austempering time.

Table III. Stabilized Weight Fractions of Ferrite and Austenite in Ausferrite, Related Austempering Times and Austempering Rates

\begin{tabular}{|c|c|c|c|c|}
\hline & $\begin{array}{l}\text { Time } \\
(\mathrm{min})\end{array}$ & $\begin{array}{l}\text { Austenite } \\
\text { Wt. Frac. } \\
\text { (pct) }\end{array}$ & $\begin{array}{c}\text { Ferrite } \\
\text { Wt. Frac. } \\
\text { (pct) }\end{array}$ & $\begin{array}{c}\text { Austempering } \\
\text { Rate (wt pct } \\
\left.\min ^{-1}\right)\end{array}$ \\
\hline $\begin{array}{l}673 \mathrm{~K}\left(400{ }^{\circ} \mathrm{C}\right), \\
\text { alloy I }\end{array}$ & 15 & $25 \pm 1$ & $75 \pm 2$ & $5.00 \pm 0.13$ \\
\hline $\begin{array}{l}673 \mathrm{~K}\left(400^{\circ} \mathrm{C}\right), \\
\text { alloy II }\end{array}$ & 25 & $35 \pm 1$ & $65 \pm 1$ & $2.60 \pm 0.04$ \\
\hline $\begin{array}{l}623 \mathrm{~K}\left(350^{\circ} \mathrm{C}\right), \\
\text { alloy II }\end{array}$ & 30 & $30 \pm 1$ & $70 \pm 2$ & $2.33 \pm 0.07$ \\
\hline
\end{tabular}

a constant value depending on the heat treatment regimen and the alloy composition. This value for alloy I austempered at $673 \mathrm{~K}\left(400{ }^{\circ} \mathrm{C}\right)$ is $312 \pm 53 \mathrm{HV}$. For alloy II austempered at $623 \mathrm{~K}\left(350{ }^{\circ} \mathrm{C}\right)$ and $673 \mathrm{~K}$ $\left(400^{\circ} \mathrm{C}\right)$, the values are $400 \pm 65 \mathrm{HV}$ and $327 \pm$ $55 \mathrm{HV}$, respectively.

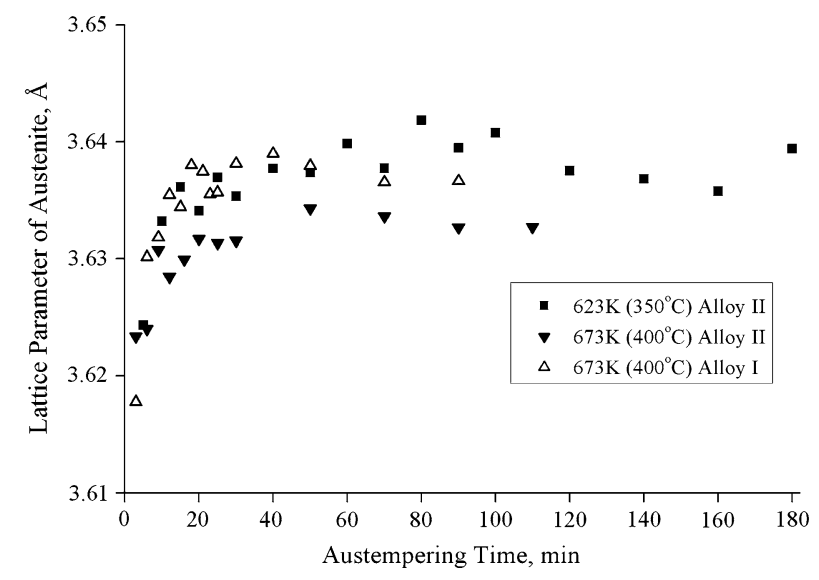

Fig. 4-The lattice parameter of austenite as a function of the austempering time. The error is $\sim 0.01$ pct.

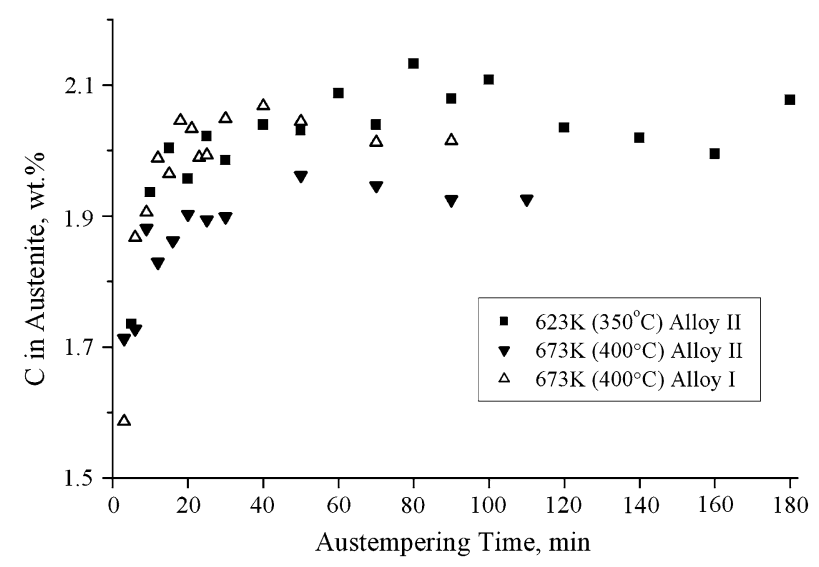

Fig. 5-The carbon concentration (wt pct) in the austenite as a function of the austempering time. The error is $\sim 0.41$ pct.

\section{DISCUSSION}

\section{A. The $\gamma \rightarrow \alpha$ Transformation Characteristics}

The austenite to ferrite transformation can be discussed in the light of the free energy diagram and the related section of the $\mathrm{Fe}-\mathrm{C}$ phase diagram, as schematically shown in Figure 9. The $\mathrm{T}_{0}$ line represents schematically the locus of points, for which austenite and ferrite have equal free energies. $\mathrm{Ae}_{1}$ and $\mathrm{Ae}_{3}$ lines are the equilibrium compositions of ferrite and austenite, respectively. The $\gamma \rightarrow \alpha$ transformation may occur when the carbon content in the austenite is below $\mathrm{X}_{\mathrm{T} 0}$, the concentration in which the austenite and ferrite have the same free energy. In this case, the free energy of austenite is higher than that of ferrite, and hence, the austenite can transform to ferrite. ${ }^{[7,8]}$ Increasing the austempering temperature decreases the concentration $\mathrm{X}_{\mathrm{T} 0}$, and the driving force for the ausferrite transformation decreases. The addition of austenite stabilizer, such as $\mathrm{Cu},{ }^{[9,10]}$ means that at the austempering temperature, its free energy (shown in Figure 9) is lower, 


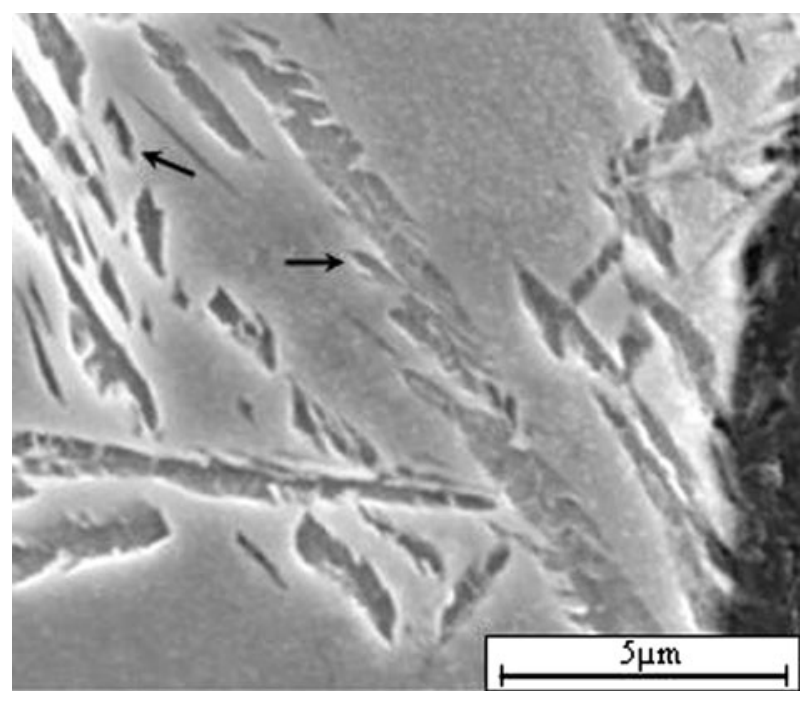

Fig. 6 - SEM image of alloy II austempered for 3 min at $673 \mathrm{~K}$ $\left(400{ }^{\circ} \mathrm{C}\right)$. The arrows indicate a typical ferrite unit.

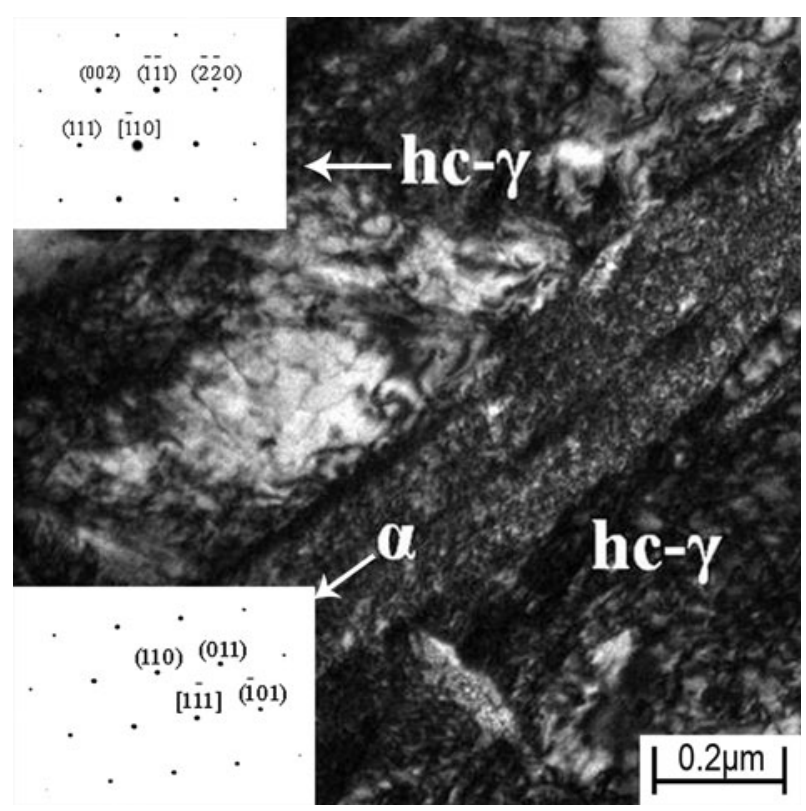

Fig. 7-A typical TEM micrograph (BF image) of alloy II austempered at $673 \mathrm{~K}\left(400{ }^{\circ} \mathrm{C}\right)$ for $6 \mathrm{~min}$ and the SAD of austenite and ferrite.

which shifts the concentration $\mathrm{X}_{\mathrm{T} 0}$ to lower values. The lower $\mathrm{X}_{\mathrm{T} 0}$ the less ferrite may be formed, because only austenite with carbon concentration lower than $\mathrm{X}_{\mathrm{T} 0}$ may transform to ferrite.

The $\gamma \rightarrow \alpha$ transformation can be understood based on the Fe-2Si-C equilibrium phase diagram, in which a metastable extension of $\alpha+\gamma$ region is drawn (Figure 10). It can be observed that an alloy containing $3.6 \mathrm{wt}$ pet carbon austenized at $1173 \mathrm{~K}\left(900{ }^{\circ} \mathrm{C}\right)$ is composed of graphite and "primary" austenite, which contains $0.75 \mathrm{wt}$ pct carbon. After rapid cooling to the austempering temperature $\left(250{ }^{\circ} \mathrm{C} \div 450{ }^{\circ} \mathrm{C}\right)$ the alloy enters to the $\alpha+\gamma$ metastable region, where the

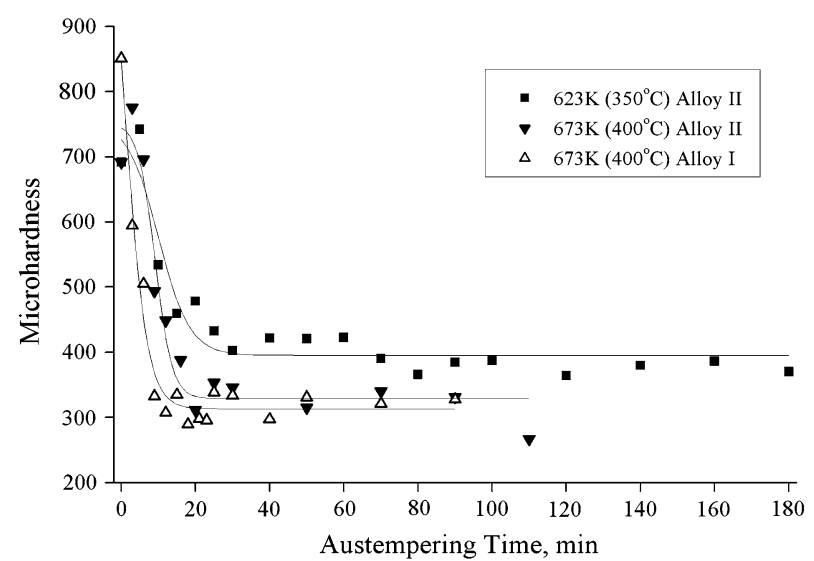

Fig. 8-Microhardness of ADI samples as a function of austempering time. The error is $\sim 17$ pct.

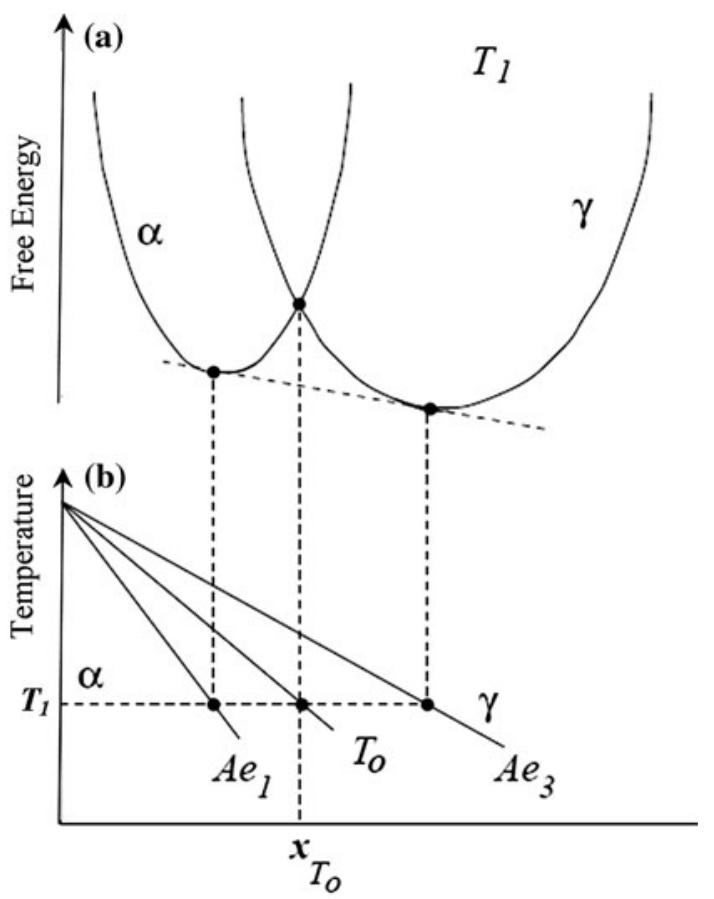

Carbon Concentration

Fig. 9- (a) A schematic free energy diagram of austenite and ferrite, and $(b)$ a related schematic section of the $\mathrm{Fe}-\mathrm{C}$ phase diagram. ${ }^{[7]}$

"primary" austenite decomposes to ferrite and hc- $\gamma$, in which the carbon content may reach 2 wt pct $\div$ 2.5 wt pct. The hc- $\gamma$ does not transform to martensite after rapid cooling because the martensite start temperature $\left(\mathrm{M}_{\mathrm{S}}\right)$ at high carbon content decreases to low values, even below room temperature ${ }^{[12]}$ as shown schematically in Figure 10. The austenite to ferrite transformation occurs as a displacive transformation, ${ }^{[13-18]}$ which results in the formation of carbon supersaturated ferrite needles, followed by carbon diffusion from the ferrite needles into the surrounding austenite. This results in an increase in the carbon content in the austenite. Because the subsequent ferrite 


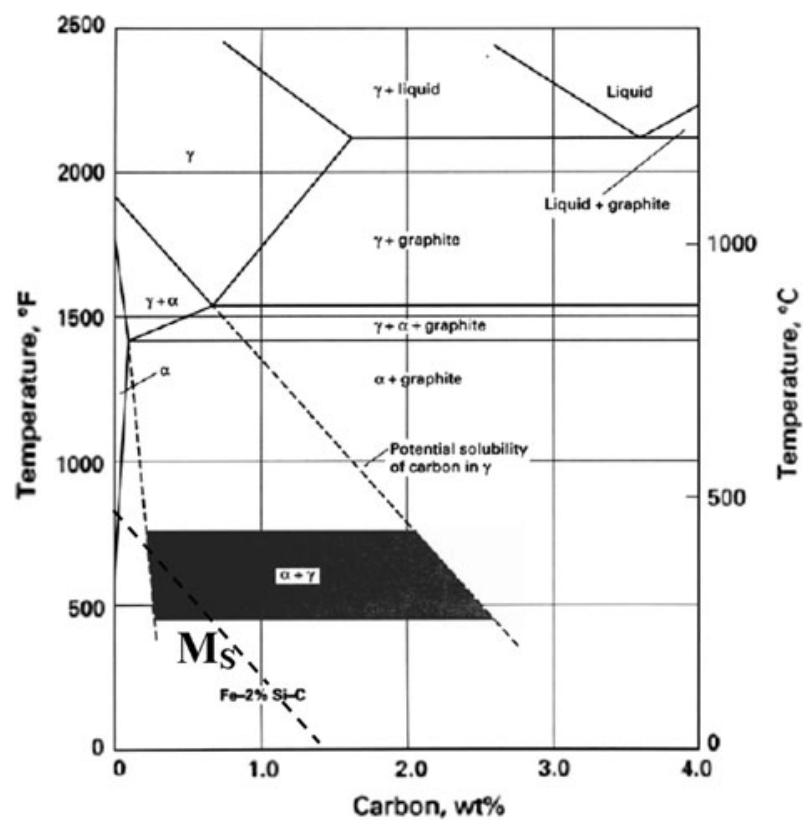

Fig. 10-A section of the Fe-2Si-C equilibrium phase diagram with a metastable projection of the $\alpha+\gamma$ two-phase region into the bainite transformation temperature range. ${ }^{[11]}$ The martensite start line $\left(\mathrm{M}_{\mathrm{S}}\right)$ is marked schematically. An alloy containing $3.6 \mathrm{wt}$ pet carbon austenized at $1173 \mathrm{~K}\left(900^{\circ} \mathrm{C}\right)$ is composed of graphite and austenite. After rapid cooling to the austempering temperature, the alloy enters to the $\alpha+\gamma$ metastable region, where the "primary" austenite decomposes to ferrite and hc- $\gamma$, in which the carbon content may reach 2 wt pct $\div 2.5$ wt pct.

nucleation can occur only in areas where the carbon concentrations in the austenite are less than $\mathrm{X}_{\mathrm{T} 0}$, a certain incubation time ${ }^{[17]}$ for the next ferrite needle to nucleate is required to enable the carbon atoms in the austenite to diffuse to distances away enough from the first needle. Therefore, the austempering rate depends on the diffusion rate and, thus, on the austempering temperature.

The results will be discussed on the basis of these characteristic of the $\gamma \rightarrow \alpha$ transformation.

\section{B. Analysis of the Results}

The first ferrite needles nucleate in the vicinity of graphite/austenite interfaces (Figure 1(a)). Subsequent needles nucleate on the already existing ferrite needles, so that the entire structure of the ferrite phase is sheaf like (Figure 6), as reported elsewhere. ${ }^{[14,17]}$ In the final microstructure, the ferrite sheaves, which grew on the graphite nodules, are surrounded by the hc- $\gamma$ (Figure 7). During this stage, the carbon atoms diffuse from the ferrite needles to the surrounding austenite, resulting in an increase in the carbon content in the austenite, as shown in Figure 5. For example, in alloy I, heat treated at $673 \mathrm{~K}\left(400{ }^{\circ} \mathrm{C}\right)$, the carbon content increases from $1.59 \mathrm{wt}$ pct (after 3 minutes) to $2.05 \mathrm{wt}$ pct (after 20 minutes of austempering) and then does not change.

The weight fractions of the ferrite and hc- $\gamma$ increase with the austempering time and reach constant values (Figure 3, Table III). These values depend on the initial carbon content of austenite reached during austenization (prior to austempering). In addition, it depends on the alloy composition, namely, on the amount of austenite stabilizers, e.g., copper. The austenite stabilizer increases the equilibrium austenite fraction, $\mathrm{f}_{\mathrm{A}}$, at $900{ }^{\circ} \mathrm{C}$ at the expense of graphite. Because $\mathrm{f}_{\mathrm{A}}$ and the amount of $\mathrm{C}$ dissolved in the austenite $\mathrm{C}_{\mathrm{A}}$ follow the relation $\mathrm{f}_{\mathrm{A}}=\left(1-\mathrm{C}_{0}\right) /\left(1-\mathrm{C}_{\mathrm{A}}\right)$, where $\mathrm{C}_{0}$ is the average carbon content in the alloy, increasing the equilibrium austenite fraction, $\mathrm{f}_{\mathrm{A}}$, increases the initial carbon content in the austenite. According to the metastable phase diagram for the $\alpha+\gamma$ region (Figure 10), the higher the carbon dissolved in austenite $\mathrm{C}_{\mathrm{A}}$, the larger the austenite weight fraction at austempering temperature. Accordingly, one can observe that the $\sim 0.7$ wt pct $\mathrm{Cu}$ increases the hc- $\gamma$ fraction from $\sim 25 \mathrm{wt}$ pct in alloy I to $\sim 35 \mathrm{wt}$ pct in alloy II. However the average carbon content in hc- $\gamma$ decreases from $\sim 2.05 \mathrm{wt}$ pct for alloy I to $\sim 1.95 \mathrm{wt}$ pet for alloy II (Figure 5), as explained previously.

The austempering rate (equals the maximum wt pct of ferrite divided by the time required to reach it) depends on the alloy additions, such as copper. The addition of copper decreases the austenite free energy (Figure 9), which results in a decrease of the driving force for the $\gamma \rightarrow \alpha$ transformation and hence the austempering rate decreases too (Table III): $\sim 0.7$ pct copper addition decreases the austempering rate from $\sim 5 \mathrm{wt}$ pct minute ${ }^{-1}$ in alloy I to $2.6 \mathrm{wt}$ pct minute ${ }^{-1}$ in alloy II.

The effect of austempering temperature was investigated by comparing the samples of alloy II austempered at $673 \mathrm{~K}\left(400{ }^{\circ} \mathrm{C}\right)$ and $623 \mathrm{~K}\left(350{ }^{\circ} \mathrm{C}\right)$. According to $\mathrm{XRD}$ results (Figure 3 ), the ferrite maximum weight fraction of $\sim 70$ pct was reached after austempering for $\sim 30$ minutes at $623 \mathrm{~K}\left(350^{\circ} \mathrm{C}\right)$, whereas that of the counterpart austempered at $673 \mathrm{~K}\left(400{ }^{\circ} \mathrm{C}\right)$ was only $\sim 65$ pct, which was reached after $\sim 25$ minutes. One can conclude that increasing the austempering temperature decreases the final ferrite fraction. These observations are in agreement with the results obtained elsewhere. ${ }^{[6-18]}$

The lower the austempering temperature, the lower the ferrite free energy relative to that of the austenite. Therefore, the $\mathrm{X}_{\mathrm{T} 0}$ concentration (Figure 9) increases. Because austenite with a carbon concentration $\mathrm{X}_{\mathrm{T} 0}$ and lower may transform to ferrite, the higher $\mathrm{X}_{\mathrm{T} 0}$, the more ferrite can be formed. ${ }^{[7]}$ The increased difference between the free energy of the ferrite and the austenite means an increase in the driving force for ausferrite transformation. Consequently, a decrease in the critical size of the ferrite needles can be expected as observed and shown in Table II: The average needle length at $623 \mathrm{~K}\left(350{ }^{\circ} \mathrm{C}\right), 0.85 \mu \mathrm{m}$, was smaller than at $673 \mathrm{~K}$ $\left(400{ }^{\circ} \mathrm{C}\right), 1.13 \mu \mathrm{m}$, whereas the average needle thickness, $0.19 \mu \mathrm{m}$, was the same.

The austempering rate (equals the maximum wt pct of ferrite divided by the time required to reach it, Table III) of alloy II at $673 \mathrm{~K}\left(400{ }^{\circ} \mathrm{C}\right)$, is $\sim 2.6 \mathrm{wt}$ pct minute ${ }^{-1}$, which is slightly higher than that at $623 \mathrm{~K}\left(350^{\circ} \mathrm{C}\right)$, $\sim 2.33$ wt pct minute ${ }^{-1}$, despite the lower transformation driving force at higher temperatures. However, a higher diffusion rate of carbon at $673 \mathrm{~K}\left(400{ }^{\circ} \mathrm{C}\right)$ reduces the incubation time for nucleation of the new ferrite needles 
and, by this means, increases the effective ferrite nucleation rate, as discussed previously.

The variation in the austenite fraction and the hc- $\gamma$ carbon content with austempering temperature can be also understood with reference to the Fe-2Si-C metastable phase diagram (Figure 10). As the austempering temperature decreases, the carbon solubility in the austenite increases, and the austenite fraction decreases according to the lever rule, and vice versa. Increasing the austenite fraction is associated with a decrease in the carbon content of hc- $\gamma$. This result is connected with carbon conservation: Because the carbon content in the ferrite is negligible, all carbon atoms present in the austenite after austenization remain in the hc- $\gamma$ after austempering. Therefore, the carbon content in the austenite is inversely proportional to the austenite weight fraction: $\sim 2.1 \mathrm{wt}$ pct $\mathrm{C}$ after austempering at $623 \mathrm{~K}\left(350^{\circ} \mathrm{C}\right)$ in which 30 wt pet hc- $\gamma$ was found and $\sim 1.95$ wt pet $\mathrm{C}$ after austempering at $673 \mathrm{~K}\left(400{ }^{\circ} \mathrm{C}\right)$, in which 35 wt pet hc- $\gamma$ was found.

The microhardness behavior (Figure 8) correlates with the changes in amounts of phases as found by XRD (Figure 3). Water quenching from austenization results in maximum microhardness because the whole matrix is martensitic. During austempering, the microhardness decreases in accordance with the decomposition of the initial austenite to ferrite and hc- $\gamma$, because the ferrite is more ductile than the martensite and the austenite, the microhardness decreases with austempering time. After a certain time (Table III), the microhardness reaches a minimum value (for a specific alloy) and then remains constant. This constant value depends mostly on the austenite weight fraction in the ausferrite microstructure and on the carbon content in the austenite. The combination of these two parameters provides the highest level of microhardness for alloy II austempered at $350{ }^{\circ} \mathrm{C}$ (Figure 8).

\section{CONCLUSIONS}

The first stage of austempering is a $\gamma \rightarrow \alpha$ displacive transformation, which takes place in the vicinity of graphite/austenite interface, resulting in ferrite needles supersaturated with carbon. Subsequently, the carbon in the ferrite needles diffuses into the surrounding austenite resulting in an increase in the carbon in the austenite, and its decrease in the ferrite. Subsequent ferrite nucleation occurs when the carbon atoms in the austenite close to the ferrite diffuse to distances away enough from the first needle. The decreased concentration near the ferrite enables the next ferrite needle to nucleate on it. Therefore, the austempering rate depends on the transformation driving force and the carbon diffusion rate.

Based on this model, the influence of copper addition and austempering temperature on the following process characteristics is as follows.
1. Increased $\mathrm{Cu}$ : The austenite fraction in the alloy increases after austenization and after austempering, whereas the final carbon content in the austenite decreases.

2. Decreased austempering temperature: The austenite fraction decreases, the austenite carbon content increases, and the ferrite needles are refined.

\section{ACKNOWLEDGMENTS}

This joint research project is supported financially by the state of Lower-Saxony (Niedersachsen), Hannover, Germany, within a joint Niedersachsen-Israel research project. The authors are also grateful to Ingo Schmidt, ACO Guss GmbH, Kaiserslautern, Germany, for the casting and to Casting Laboratory, Israel Institute of Metals, Technion, Israel for using their facility for heat treatment. Thanks to Dr. Uwe Wasmuth for carrying out the color metallography. Special thanks to Dr. Leopold Meier for collaborating with the preparations for color metallography and discussing this article.

\section{REFERENCES}

1. M. Bahmani, R. Elliott, and N. Varahram: J. Mater. Sci., 1997, vol. 32, pp. 4783-91.

2. U. Batra, S. Ray, and S.R. Prabhakar: J. Mater. Eng. Perform., 2007, vol. 16, pp. 485-89.

3. M. Tayanç, K. Aztekin, and A. Bayram: Mater. Des., 2007, vol. 28, pp. 797-803.

4. Rio Tinto Iron \& Titanium Inc., Ductile Iron Group: Ductile Iron Data for Design Engineers, $2^{\text {nd }}$ ed., Rio Tinto Iron \& Titanium Inc., Canada, 1998, section IV.

5. P. Schaaf, S. Cusenza, M. Bamberger, Y. Amran, K. Weiss, L. Meier, U. Wasmuth, and M. Hofmann: Int. Foundry Res., 2009, vol. 61, pp. 14-21.

6. S.K. Putatunda, S. Kesani, R. Tackett, and G. Lawes: Mater. Sci. Eng. A, 2006, vols. 435-436, pp. 112-22.

7. M.A. Yescac-González: Ph.D Dissertation, University of Cambridge, Cambridge, UK, 2001.

8. G.I. Rees and H.K.D.H. Bhadeshia: Mater. Sci. Technol., 1992, vol. 8, pp. 985-93.

9. J. Aranzabal, I. Gutierrez, J.M. Rodriguez-Ibabe, and J.J. Urcola: Metall. Mater. Trans. A, 1997, vol. 28A, pp. 1143-56.

10. Y. Mi: Scripta Metall. Mater., 1995, vol. 32, pp. 1313-17.

11. J.R. Davis: Cast Irons, ASM Specialty Handbook, ASM International, Material Park, OH, 1996, p. 194.

12. K.B. Rundman: "It's About Austenite and Carbon, Mate" - A Story of the Physical Metallurgy of ADI - Part II, The 35th Australian Foundry Institute National Conference, Adelade, Australia, 2004

13. D. Gaude-Fugarolas: ISIJ Int., 2006, vol. 46, pp. 712-17.

14. K. Laneri, P. Bruna, and D. Crespo: Mater. Sci. Technol., 2008, vol. 24, pp. 1214-21.

15. N.A. Chester and H.K.D.H. Bhadeshia: J. Phys. IV, 1997, vol. 7, pp. 41-46.

16. Z. Ławrynowicz and S. Dymski: Adv. Mater. Sci., 2008, vol. 8, pp. 80-93.

17. H. Bhadeshia and J. Christian: Metall. Trans. A, 1990, vol. 21A, pp. 767-97

18. M. Takahashi: Curr. Opin. Solid State Mater. Sci., 2004, vol. 8, pp. 213-17. 